\title{
Introduction: What is multilevel governance?
}

\author{
Arthur Benz, Jörg Broschek and Markus Lederer
}

\section{Introduction}

Over the last decades, the concept of multilevel governance (MLG) has stimulated fascinating research on the changing nature of political authority. Scholars have discovered the complexity, variety and dynamics of governance in multilevel settings within and beyond nation states, probed the merits of different explanations of these changes and, eventually, studied the consequences for politics, policymaking and democratic legitimacy. Thanks to this research, we have a good understanding of the underlying theoretical foundations of MLG, its historical evolution, its varieties and political dimensions. Yet the advancement of scientific research has come at a price. On the one hand, highly sophisticated and empirically rich research has revealed various patterns of MLG and many intricate details regarding their evolution, operation and consequences (Bache and Flinders 2015; Enderlein, Wälti and Zürn 2010; Piattoni 2010). On the other hand, the concept has lost its analytical clarity and tends to become a catch-all category (Stephenson 2013: 817-818). There is obviously need for a conceptual framework that does not conceal but explicates different aspects covered by the term. Such a framework is essential to guide comparative research that reflects varieties of MLG and contributes to advance theoretical reasoning on the causes, operation and consequences for politics and policymaking.

This chapter suggests a framework that can delineate and structure the research field. It starts with a definition of the term MLG. In addition, it identifies basic analytical dimensions reflected in research perspectives on MLG. This framework allows us to map research and to account for the selection of the topics covered in this volume. 
The articles collected in this volume provide more than a stock-taking of the state of the art. By critically engaging with theoretical and empirical research on different aspects of MLG, they also outline avenues for further research. Without presuming to include all potential research topics, we shed light on the different contexts to which MLG has been or should be applied and indicate relevant subjects and research questions - questions that either warrant further exploration or that have not been addressed at all.

\section{The Concept of Multilevel Governance}

Defining a concept requires that we demarcate what it includes and what it does not include, both with regard to the empirical reality, which it intends to describe, and the analytical perspective applied to this reality. While it relates to different political contexts, the concept of MLG describes the differentiation and coordination of political authority across scales of jurisdiction. The emergence of MLG results from an increasing complexity of problems that often cross existing jurisdictional and functional boundaries. Analytically, MLG thus captures structures and processes of governing. Structures are characterized by a division of power between different tiers of territorial units (local, regional, national, continental and global) that either are congruent, as is typical for states or federations, or overlap as function-specific jurisdictions (Hooghe and Marks 2003). Reacting to interdependent policy challenges - such as new kinds of violent conflicts, climate change, migration, economic stability, the digitalized 'network society' (Castells 1999) or a pandemic - and to external effects of policies or private activities, processes of governance aim at coordinating political decisions at different levels. Or, and even more ambitious, these new governance arrangements lead to institutional change through the constant renegotiation and adjustment of authority.

While most scholars agree on the general definition of MLG, the precise understanding of the components of the concept is disputed. This mostly concerns the term governance. In research on MLG, this term indicates a structured constellation of state and/or non-state actors who interact in informal or formal ways to achieve common goals (Benz 2009: 15-18; Risse 2011). Levels usually are considered as territorially delineated jurisdictions of different scales, yet MLG encompasses a vertical and horizontal dimension. Accordingly, it can also entail coordination among jurisdictions residing on a similar scale, such as sub-federal units within or between adjacent federations (Behnke, Broschek and Sonnicksen 2019). Aside from territorial boundaries, 
levels are also defined by communities. The boundaries of communities do not necessarily correspond with a territory, as one can assume for the relationship between a state and its communities of citizens. In addition, levels constitute arenas of politics and are characterized by a particular institutional context, usually represented by governmental and/or bureaucratic actors. The attribute 'multi' refers to the number of levels, which cannot be defined without an empirical case at hand. Most policies span several levels. Major policy challenges have local as well as global dimensions, and political authorities cope with these problems at and across various levels, sometimes unilaterally but, more often than not, through coordinated policymaking. Although the number of levels involved cannot be defined in a general concept, it seems reasonable to assume that MLG, for the most part, includes actors representing two or three levels of authority. Finally, another defining feature of MLG is the sequential compartmentalization of decision-making: different phases of the policy cycle often take place on different scales, involving different types of actors (see also Tatham, Chapter 8, this volume).

We suggest that this definition contributes to sharpening the conceptual boundaries of MLG. First, we distinguish MLG and intergovernmental relations, as the latter focuses on governments or executives and administrators as actors (see also Alcantara, Broschek and Nelles 2016). Intergovernmental politics can and usually does contribute to MLG, but the concept is more specific. Research on MLG originated in European studies and in studies on federal systems. Federalism or federations characterize multilevel political systems in which powers are divided and governments or executives may need to coordinate interdependent policies. These actors engage in MLG, and so do executives of national, regional or local governments in regionalized or unitary states. The literature on territorial politics and regionalism also relates to MLG, as it addresses how politics is shaped by territorial structures, but it emphasizes territorial divisions - or 'self-rule' - rather than interdependence and coordination across levels. Finally, global governance is empirically most often a specific form of MLG but conceptually focuses mainly on the global dimension without taking into account the interplay with other levels.

This definition allows us to advance the analytical framework distinguishing various structures and processes of governance. Spheres of authority can be separated and allow self-rule at different levels. Alternatively, these spheres can overlap and establish shared rule. Structures can be entrenched in a constitution, but they also result from continuous and rather informal processes of 'authority migration' (Gerber and Kollman 2004). Either way, governance is about managing interdependence, although the ways to achieve coordinated action vary. Self-rule usually results in unilateral or mutual adjustments, but 
also requires policymakers to coordinate decisions in ad hoc interactions or more durable, yet still informal and network-like, governance settings. Shared rule, by contrast, implies some form of institutionalized or established interaction aiming at negotiated agreements. Patterns of coordination among jurisdictions range from indirect modes - such as policy transfer and diffusion or various forms of competition that induce or compel governments or other actors to adapt their policy to a common standard or trend - to direct modes such as cooperation, joint decision-making or central regulation.

Configurations of MLG, however, do not only vary in terms of the division of power, their persistence, the degree of institutionalization or their modes of coordination, but also in terms of the actors they encompass. As MLG implies the exercise of political authority, it usually (although not necessarily always) relies on executives representing different territorial jurisdictions. More often than not, other actors and stakeholders, such as arbiters or judges, experts, corporations, non-governmental organizations (NGOs) or unions, also play a role. Within the respective territorial units, and in accordance with established procedures, responsible governmental actors are held accountable by the community of citizens they represent. While participating in multilevel policymaking, actors remain linked to the particular system of government. Accordingly, executives have to anticipate that parliaments scrutinize multilevel policymaking, and that majority parties can even use their veto power to jeopardize negotiated agreements. Members of parliaments from different jurisdictions may exchange information in 'interparliamentary relations' (Crum and Fossum 2013), although they rarely are directly involved in processes of MLG. Private actors can approach executives from upper and lower levels to lobby for their interests and benefit from multiple access points (Eising 2004). Moreover, they can be included directly in policy processes as experts or stakeholders, but they may also face a closed network of executives which shields policymaking against external influences (Grande 1996). For these reasons, MLG has to be conceived as a complex process linking intra-, inter- and transgovernmental 'arenas' of governance.

Research has identified different patterns of MLG depending on the local, regional, national and international contexts. Within states, the territorial organization of governments (unitary or federal; centralized or decentralized), the political regime (autocratic or democratic) and varieties of democracy (parliamentary or non-parliamentary; majoritarian or consensus) make a difference concerning the structure and operation of MLG. When it comes to politics beyond the nation state, they usually include executives from international organizations and nation states. Here, we also witness a rise in the participation of global as well as local non-state actors (e.g. private firms, 
NGOs, civil society representatives). International governance without the involvement of government agents rarely has a multilevel character, although it has proven to provide governance services on a sectoral level particularly when the degree of statehood is weak (Beisheim, Ellersiek and Lorch 2018).

Within nation states, decentralization and regionalization have increased the need for multilevel policy coordination since the 1970s. Hence, the expansion of MLG can be considered a consequence of the transformation of the state, be it due to the 'rise of regional authority' (Hooghe, Marks and Schakel 2010) or to European integration and globalization (Hooghe, Lenz and Marks 2019; Hooghe and Marks 2001). Various scholars have shown that the state still constitutes an institutional framework, provides legitimacy and enables or constrains interactions among powerful actors who are attached to states - even in areas where the state provides an ideal rather than a reality (see contributions in Risse, Börzel and Draude 2018). Whether MLG materializes within a state or between and beyond states makes a difference, but the challenges to managing complex processes are comparable.

\section{Mapping Research on Multilevel Governance}

Research on MLG has been enriched from theoretical and empirical work in different areas. In particular, the concept became popular in studies on European integration during the 1990s when it was introduced by Liesbet Hooghe and Gary Marks to capture the simultaneous advancement of the European Community towards a more closely integrated European Union (EU) and the rise of regions as new actors in national and European politics (Hooghe and Marks 2001). This dispersion of political authority from the nation state to the EU and regions prompted a critical reconsideration of existing integration theories that did not adequately capture the rise of new patterns of divisions of power and policy coordination between the European Commission and regional or local governments of member states. Reforms and implementation of Regional Structural Funds clearly demonstrated these changes, and many studies on MLG in the EU focused on this policy field.

Similar processes of restructuring the territorial organization of politics and the evolution of multilevel policymaking had been observed within nation states. In federal states, scholars described and analyzed intergovernmental relations or instances of cooperative federalism (Poirier, Saunders and Kincaid 2016; Simeon 2006; Wright 1988). Empirical studies on intergovernmental relations 
revealed various actor constellations, and it is not surprising that research on federalism and on European policymaking both stimulated the conceptual and theoretical advancement of research on MLG. Fritz W. Scharpf's works on joint decision-making, and later on varieties of 'multilevel governing', exemplify this (Scharpf 1988; 2001; 2006). Scharpf drew on comparative research on policymaking in German federalism and in the European Community or EU.

Studies on central-local relations can be taken as another source of empirical research on MLG (Goldsmith and Page 2010). They have focused on how central governments intervene in local policies and how local governments influence central legislative and executive decisions. Depending on the structure of states (unitary, regionalized, federal) and other institutional conditions, research revealed asymmetric power structures favouring central government, central-local networks, antagonistic politics or a division of functions that are fulfilled by complementary policies.

Finally, the MLG concept travelled to the realm of international politics where, traditionally, structures had been described as anarchic (Waltz 1979) or as being dominated by a hegemon (Gilpin 1981). During the 1980s, the literature on regimes (Krasner 1983) stressed that 'cooperation after hegemony' (Keohane 1984) is not only a possible but a regular pattern of international politics. After the end of the Cold War, the notion of global governance (Rosenau 1992; Zürn 2018) adopted this concept and, in addition, pointed out that 'private authority' (Cutler, Haufler and Porter 1999) can and in fact does constitute a functional alternative to the authority of international organizations. Inspired by insights from studies on European integration, scholars of international relations learned that the levels of governance are deeply intertwined (Putnam 1988) and that MLG in the international sphere appears in different policy sectors and is hence characterized by significant variation. Moreover, global patterns of MLG coexist with deepened regional integration while, at the same time, great powers like Russia, China and the US still play a unique role providing elements of hierarchy within the international system (Lake 2013). In short, on the international level MLG often reveals complex relations between states, regional confederations of states like the EU, intergovernmental conferences, international organizations, non-state actors and quasi-governmental international bodies, which constitute more or less asymmetric 'Multilevel Action Systems' (Mayntz 2015).

Within these research fields, scholarship on MLG has dealt with three basic questions, and the need for further research can be identified with regard to these topics. They relate to structures and institutional configurations and 
their dynamics (polity), actors and power relations (politics) and issues, interaction and coordination (policy).

\subsection{The evolution, structures and institutional configuration of multilevel governance}

In view of the transformation of the state, empirical research has uncovered changes in the distribution of power within and beyond states. Different theories explain these changes as a rise of MLG and the evolution of institutional configurations of politics. The post-functionalist approach elaborated by Hooghe and Marks has been most influential. It claims that functional pressure causes a shift of authority from nation states to the EU and international organizations. At the same time, communities of citizens supported by political parties demand more autonomy for subnational regions (Hooghe and Marks 2009; see also Hooghe and Marks, Chapter 1, this volume). In an actor-centred perspective, Marks, Scharpf and others have explained MLG as driven by executives and bureaucrats interested in multilevel policymaking, either to better fulfil their tasks or to escape the control of parliaments or other powerful domestic actors (Marks 1996; Scharpf 1997b). This approach has also been taken up in studies addressing transgovernmental arenas that emerged in international relations (e.g. Slaughter 2000).

While these theories and empirical studies elucidate the evolution of MLG, research has also pointed out distinct configurations of MLG, such as those structured by territories and those linking function-specific jurisdictions, those emerging in the shadow of a hierarchical order and those constituted by institutionalized power-sharing. The evolution of governance may be directed from the top or evolve from the bottom up, and sometimes it is driven by interaction among executives or non-governmental actors across specific scales circumventing a constitutional order - for instance, if regional or local governments bypass the national government in transnational governance. These varieties of structures and dynamics call for further comparative research, not least because neither the causes explaining the different structures nor their consequences are sufficiently understood. Given that MLG reveals significant aspects of the transformation of the state since about the late 1970s, research on this historical process might offer an interesting point of departure for theorizing MLG (Leibfried and Zürn 2005). Moreover, recent discussions about differentiated integration and disintegration in the EU (Leuffen, Rittberger and Schimmelfennig 2012) can contribute to better understanding the evolution and change of MLG. All these insights explain the dynamic nature of MLG. 
Focusing on the interplay of the intra- and intergovernmental dimension, the evolution of MLG has often been criticized for causing or aggravating a democratic deficit (Hurrelmann, Chapter 2, this volume). In federal states, scholars have observed a shift in power from parliaments to the executive, and similar consequences have been traced to MLG in the EU, although both the European Parliament and national parliaments made efforts to respond to 'executive federalism'. This concept, however, conceals the internal differentiation of the executive (Trondal, Chapter 3, this volume). In multilevel policymaking, political leaders accountable to parliaments and political parties negotiate and conclude agreements. However, civil servants have to prepare these decisions and settle conflicts in details. Coming from more or less specialized administrations, they tend less to political bargaining and rather cooperate with a professional interest in problem-solving. This is still a neglected aspect of MLG, although we observe a turn to the administrative dimension of MLG in research on EU and international politics (Egeberg 2006; Trondal et al. 2010: 171-190).

Nonetheless, MLG raises concerns about democratic legitimacy (DeBardeleben and Hurrelmann 2007). To cope with deficits, various proposals of a multilevel democracy have been advanced, including stakeholder participation, deliberative democracy, multilevel parliamentarism or demoi-cracy. While these concepts intend to improve input-legitimacy, scholars have also reflected on the relevance of output- and throughput-legitimacy (Scharpf 1999; Schmidt and Wood 2019; Wolf 2006). Still, the debate is influenced by the perception that national and regional parliaments and, accordingly, the public in general are losing out in MLG. More recently, a promising research perspective suggests a nuanced understanding that draws attention to the ways in which democratic government and MLG are linked. It calls for analyzing the responses of parliaments to executive dominance and exploring ways of balancing power between elected and non-elected actors. In this context, the functional differentiation and the interplay of political and administrative patterns of MLG have to be reconsidered (Benz and Sonnicksen 2017).

Moreover, while scholars have emphasized the rule of law as a source to legitimize global governance (Reus-Smit 2004), the impact of MLG on the evolution of law and the interplay of politics and courts in multilevel systems still deserves more attention in research. This does not mean to suggest a legalist approach to MLG. Studies on European integration and comparative federalism point out the risk of over-constitutionalization and rigidity, but also of a politicization of courts. However, at the global level, a strengthening of international administrative law is clearly perceived as a necessity (Ming-Sung 
2019). The role of law in MLG deserves definitively more attention in research (Dawson, Chapter 4, this volume).

Widely neglected so far in research on MLG is digitalization. At a glance, it is obvious that communication via the Internet has significant advantages and comes with serious risks. Yet we hardly know how digital communications affects politics and policymaking in MLG and whether or how it changes governance structures. The increasing relevance of online interaction caused by the COVID-19 pandemic highlights this research gap (Roy, Chapter 5, this volume).

\subsection{Actors and power}

MLG changes structures but also mobilizes actors against established power-holders (Marks 1996; Piattoni 2010: 18-20). Traditionally, the authority to enter into intergovernmental agreements remains with public officials, such as national government executives or heads of international organizations. With the rise of MLG, this has not fundamentally changed. At the global level, national governments are still in the driving seat and have even regained some regulatory territory, although secretariats of international organizations have gained autonomy and authority (Hickmann et al. 2019). However, research has not only revealed that new actors have entered the scenery, like cities, regions, private actors or independent experts, it also has provided evidence that actors within states, such as parliaments, parliamentary assemblies, parties and private interest organizations, did not lose ground in the intricate and dynamic processes of governance transgressing boundaries of jurisdictions.

In Europe, national governments transferred power in the course of European integration more than in any other world region, even though Brexit has put the notion of an 'ever closer union' into doubt. Nevertheless, the EU has evolved into a corporate actor on its own in national and international politics and is represented by the European Commission (President or High Representative). In other world regions, processes of integration are under way. The progress varies and the actorness of organizations, regional associations or custom unions, like the North American Free Trade Agreement (NAFTA), African Union (AU), Association of Southeast Asian Nations (ASEAN), Southern African Development Community (SADC) or the Common Market of the South (MERCOSUR), varies, as does their power in global politics, their underlying sense of community or their impact on politics in their member states (Börzel, Chapter 6, this volume). 
The relations of various actors within nation states have been explored in much more detail. We thus know that interactions between executives, parliaments and parties significantly affect the operation of MLG (Auel, Chapter 7, this volume). Considering the responses of parliaments to emergent intergovernmental relations, scholars have studied institutional reforms, the strategic interplay of executives and parliaments and the resulting changes in power structures (Raunio and Wagner 2017). While parliaments have lost power in MLG, they responded to improve scrutiny over processes and maintain control over executive politics. Parties and multilevel party systems became a research field on its own in comparative federalism and in studies on European politics (Thorlakson 2009), whereas in international politics, the role of parties has not become a focus of MLG research.

Here, we find cities and regions as increasingly influential actors despite their lack of strong formal power resources. In policy fields like climate change, their role becomes more significant. Invited by international organizations or the European Commission, their representatives participate in international conferences or transnational networks. In MLG within states, regions have significant power in federal and regionalized states, while cities look for support from central governments to cope with problems that often are caused by the national or international context (Tatham, Chapter 8, this volume).

In the EU and in international politics, the concept of 'new modes of governance' has indicated the growing involvement of private actors and NGOs representing civil society (Mende, Chapter 9, this volume), while within states, the participation of special interest groups and experts seems to be more important. More recently, Indigenous people and national minorities are considered as actors in MLG. So far scholarship has focused on federations with divided societies, although even in this context research is still in its infancy (Breen and Thomas, Chapter 10, this volume).

Various strands of research on MLG show that different types of actors are involved in multilevel politics. Interaction, coordination and power structures are significantly influenced by the internal organization and organizational capacities of these actors as well as their interests, values, goals and action orientations. Hence, an actor-centred perspective has turned out to be a valuable approach in research on MLG (Scharpf 1997b). Actors shape institutions, ideas and patterns of interactions, in MLG more than within the context of established organizations, states or governments. Here, politics transgresses boundaries of institutions and levels, it includes actors from different ideational backgrounds, and it is less constrained by rules than guided by procedures that are continuously adjusted. 
While various scholars studying MLG have been interested in understanding the transformation of politics in a globalizing world, others inquired into the consequences of policymaking. In this context, two approaches emerged. First, a comparative public policy approach based on quantitative methods addresses the impact of a changing distribution of power on policy outcomes in particular fields (Garritzmann, Roth and Kleider 2021; Kleider 2018). It has proven that changes in the distribution of power matter, although party politics and ideologies cannot be neglected, in contrast to what normative theories of globalization or decentralization tell us (Harmes, Chapter 12, this volume). Second, actor-centred institutionalism traces processes of policymaking in different patterns of MLG and explains their impact on the effectiveness or failure of governance (Scharpf 1988; 1997b). In a comparative perspective, this research has identified different modes that are embedded in hierarchies or networks and are designed to coordinate policies by negotiations, competition, mutual adjustment or policy transfer.

There is no doubt that the effectiveness of these modes of governance varies with the policy issues to be dealt with and the intensity of conflicts to be solved. Note that joint decision-making in the EU seems to work in regulative policies while it fails to deal with redistributive policies (Scharpf 1997a). Hence, we can assume a certain correspondence between particular coordination modes and issues, such as the provision of public goods like security (Schröder, Chapter 11, this volume), redistributive fiscal and social policies (Harmes, Chapter 12 , this volume) or policies addressing complex and dynamic problems like climate change by planning, regulation and crisis intervention (VanNijnatten, Chapter 13, this volume). Policies of the latter type not only have to deal with distributive and redistributive conflicts, but also have to cope with the stability of technical and social systems. System maintenance is also a matter of institutional design and reform. In research on the evolution and changes of MLG, policies of reform have so far not been taken into account. Of course, the whole complexity of a multidimensional structure of MLG cannot be shaped or changed according to an institutional design. However, the distribution of power or the adjustment of institutions of a government, a transnational federation or an international organization do not simply emerge from power politics. They are founded and amended by agreements of governments, which in the national and European context are ratified through democratic processes. Therefore, MLG can certainly be reformed. However, it is still an open question how and to what extent this is possible either by institutional 
changes or as an implicit consequence of policy reforms (Benz and Broschek, Chapter 14, this volume).

\section{Towards a Research Agenda}

This rough sketch of gaps and potential avenues for further research is not more than a first step to design a research agenda for MLG. A second step forward will be taken with the more in-depth account on particular research fields provided in the following chapters. The authors of these chapters outline different topics of research on MLG. They provide a more detailed review of the state of research and highlight theoretical perspectives and analytical approaches that have proved useful or appear promising in the specific research fields. In view of the heterogeneity of research on the different aspects, the chapters do not follow a common structure. However, envisaging a research agenda, they emphasize particular perspectives, theoretical frameworks and analytical concepts. Moreover, as the authors are specialists in either international politics, European politics, comparative federalism, constitutional and European law or public administration, none of the articles can provide a comprehensive account of relevant research covering all levels or all varieties of MLG.

By inviting the authors, the editors selected the thematic focus on the individual chapters, and this selection was a deliberate choice emphasizing important research topics. Furthermore, it should demonstrate that the concept of MLG can inspire interesting research in different sub-disciplines of political science (international relations, European studies, comparative regionalism, comparative federalism, policy studies). Likewise, political scientists can benefit from contributions from constitutional law, economics (institutional economics, fiscal federalism) and public administration. The challenge remains, however, to work with a basic concept of MLG that is clearly demarcated against other concepts. It should imply a differentiated analytical framework that allows us to apply the concept to various contexts without losing clarity.

\section{References}

Alcantara, Christopher, Jörg Broschek and Jen Nelles (2016), 'Rethinking Multilevel Governance as an Instance of Multilevel Politics: A Conceptual Strategy', Territory, Politics, Governance, 4 (1), 33-51. 
Bache, Ian and Matthew Flinders (eds.) (2015), Multi-Level Governance. Essential Readings (2 volumes), Cheltenham, UK and Northampton, MA: Edward Elgar Publishing.

Behnke, Nathalie, Jörg Broschek and Jared Sonnicksen (2019), 'Introduction: The Relevance of Studying Multilevel Governance', in Nathalie Behnke, Jörg Broschek and Jared Sonnicksen (eds.), Configurations, Dynamics and Mechanisms of Multilevel Governance, Cham: Springer International, pp. 1-19.

Beisheim, Marianne, Anne Ellersiek and Jasmin Lorch (2018), 'INGOS and Multi-Stakeholder Partnerships', in Thomas Risse, Tanja A. Börzel and Anke Draude (eds.), The Oxford Handbook of Governance and Limited Statehood, Oxford: Oxford University Press, pp. 211-230.

Benz, Arthur (2009), Politik in Mehrebenensystemen, Wiesbaden: VS Verlag für Sozialwissenschaften.

Benz, Arthur and Jared Sonnicksen (2017), 'Patterns of Federal Democracy: Tensions, Friction, or Balance between Two Government Dimensions', European Political Science Review, 9 (1), 3-25.

Castells, Manuel (1999), The Rise of the Network Society, Cambridge, MA: Blackwell Publishing.

Crum, Ben and John Erik Fossum (eds.) (2013), Practices of Inter-Parliamentary Coordination in International Politics - The European Union and Beyond, Colchester: ECPR Press.

Cutler, Claire A., Virginia Haufler and Tony Porter (eds.) (1999), Private Authority and International Affairs, Albany: State University of New York Press.

DeBardeleben, Joan and Achim Hurrelmann (eds.) (2007), Democratic Dilemmas of Multilevel Governance, Basingstoke, New York, NY: Palgrave Macmillan.

Egeberg, Morten (ed.) (2006), Multilevel Union Administration. The Transformation of Executive Politics in Europe, Basingstoke, New York, NY: Palgrave Macmillan.

Eising, Rainer (2004), 'Multilevel Governance and Business Interests in the European Union', Governance, 17 (2), 211-245.

Enderlein, Henrik, Sonja Wälti and Michael Zürn (eds.) (2010), Handbook on Multi-Level Governance, Cheltenham, UK and Northampton, MA: Edward Elgar Publishing.

Garritzmann, Julian L., Leonce Röth and Hanna Kleider (2021), 'Policy-Making in Multi-Level Systems: Ideology, Authority, and Education', Comparative Political Studies, accessed 20 May 2021, https://doi.org/10.1177/0010414021997499.

Gerber, Elisabeth and Ken Kollman (2004), 'Introduction-Authority Migration: Defining an Emerging Research Agenda', PS: Political Science \& Politics, 37 (3), 397-401.

Gilpin, Robert (1981), War and Change in World Politics, Cambridge, UK: Cambridge University Press.

Goldsmith, Michael and Edward Page (eds.) (2010), Changing Government Relations in Europe. From Localism to Intergovernmentalism, London: Routledge.

Grande, Edgar (1996), 'The State and Interest Groups in a Framework of Multi-Level Decision Making. The Case of the European Union', Journal of European Public Policy, 3 (3), 318-338.

Hickmann, Thomas, Oscar Widerberg, Markus Lederer and Philipp Pattberg (2019), 'The UNFCCC Secretariat as an Orchestrator in Global Climate Policy-Making', International Review of Administrative Sciences, 87 (1), 21-38.

Hooghe, Liesbet, Tobias Lenz and Gary Marks (2019), A Theory of International Organization, Oxford: Oxford University Press. 
Hooghe, Liesbet and Gary Marks (2001), Multi-Level Governance and European Integration, Lanham, MD: Rowman \& Littlefield Publishers.

Hooghe, Liesbet and Gary Marks (2003), 'Unraveling the Central State, but How? Types of Multi-Level Governance', American Political Science Review, 97 (2), 233-243.

Hooghe, Liesbet and Gary Marks (2009), 'A Postfunctionalist Theory of European Integration: From Permissive Consensus to Constraining Dissensus', British Journal of Political Science, 39 (1), 1-23.

Hooghe, Liesbet, Gary Marks and Arian H. Schakel (2010), The Rise of Regional Authority. A Comparative Study of 42 Democracies, New York, NY: Routledge Chapman \& Hall.

Keohane, Robert O. (1984), After Hegemony. Cooperation and Discord in the World Political Economy, Princeton, NJ: Princeton University Press.

Kleider, Hanna (2018), 'Redistributive Policies in Decentralised Systems: The Effect of Decentralisation on Subnational Social Spending', European Journal of Political Research, 57 (2), 355-377.

Krasner, Stephen D. (ed.) (1983), International Regimes, Ithaca, NY: Cornell University Press.

Lake, David A. (2013), 'Great Power Hierarchies and Strategies in Twenty-First-Century World Politics', in Walter Carlsnaes, Thomas Risse and Beth Simmons (eds.), Handbook of International Relations, Los Angeles: Sage, pp. 555-578.

Leibfried, Stephan and Michael Zürn (eds.) (2005), The Transformation of the State?, Cambridge, UK: Cambridge University Press.

Leuffen, Dirk, Berthold Rittberger and Frank Schimmelfennig (2012), Differentiated Integration. Explaining Variation in the European Union, New York, NY: Palgrave Macmillan.

Marks, Gary (1996), 'An Actor-Centred Approach to Multi-Level Governance', Regional and Federal Studies, 6 (2), 20-38.

Mayntz, Renate (2015), 'Introduction: Regulatory Reform in a Multilevel Actor System', in Renate Mayntz (ed.), Negotiated Reform: The Multilevel Governance of Financial Regulation, Frankfurt, New York, NY: Campus, pp. 7-16.

Ming-Sung, Kuo (2019), 'Law-Space Nexus, Global Governance, and Global Administrative Law', in Diane Stone and Kim Moloney (eds.), The Oxford Handbook of Global Policy and Transnational Administration, Oxford: Oxford University Press, pp. 328-345.

Piattoni, Simona (2010), The Theory of Multi-Level Governance. Conceptual, Empirical, and Normative Challenges, Oxford: Oxford University Press.

Poirier, Johanne, Cheryl Saunders and John Kincaid (eds.) (2016), Intergovernmental Relations in Federal Systems, Oxford: Oxford University Press.

Putnam, Robert D. (1988), 'Diplomacy and Domestic Politics: The Logic of Two-Level Games', International Organization, 42 (3), 427-460.

Raunio, Tapio and Wolfgang Wagner (2017), 'Towards Parliamentarisation of Foreign and Security Policy?', West European Politics, 40 (1), 1-19.

Reus-Smit, Chris (ed.) (2004), The Politics of International Law, Cambridge, UK: Cambridge University Press.

Risse, Thomas (2011), 'Governance in Areas of Limited Statehood. Introduction and Overview', in Thomas Risse (ed.), Governance Without a State? Policies and Politics in Areas of Limited Statehood, New York, NY: Columbia University Press, pp. 1-35.

Risse, Thomas, Tanja A. Börzel and Anke Draude (eds.) (2018), The Oxford Handbook of Governance and Limited Statehood, Oxford: Oxford University Press 
Rosenau, James N. (1992), 'Governance, Order, and Change in World Politics', in James N. Rosenau and Ernst-Otto Czempiel (eds.), Governance Without Government. Order and Change in World Politics, Cambridge, UK: Cambridge University Press, pp. 1-29.

Scharpf, Fritz W. (1988), 'The Joint-Decision Trap: Lessons from German Federalism and European Integration', Public Administration, 66 (3), 239-278.

Scharpf, Fritz W. (1997a), 'Economic Integration, Democracy and the Welfare State', Journal of European Public Policy, 4 (1), 18-36.

Scharpf, Fritz W. (1997b), Games Real Actors Play: Actor-Centered Institutionalism in Policy Research, Boulder, CO: Westview Press.

Scharpf, Fritz W. (1999), Governing in Europe: Effective and Democratic?, Oxford, New York, NY: Oxford University Press.

Scharpf, Fritz W. (2001), 'Notes Toward a Theory of Multilevel Governing in Europe', Scandinavian Political Studies, 24 (1), 1-26.

Scharpf, Fritz W. (2006), 'The Joint-Decision Trap Revisited', Journal of Common Market Studies, 44 (4), 845-864.

Schmidt, Vivien A. and Matthew Wood (2019), 'Conceptualizing Throughput Legitimacy: Procedural Mechanisms of Accountability, Transparency, Inclusiveness and Openness in EU Governance', Public Administration, 97 (4), 727-740.

Simeon, Richard (2006), Federal-Provincial Diplomacy. The Making of Recent Policy in Canada, 2nd ed., Toronto: University of Toronto Press.

Slaughter, Ann-Marie (2000), Governing the Global Economy through Government Networks. The Role of Law in International Politics. Essays in International Relations and International Law, Oxford: Oxford University Press.

Stephenson, Paul (2013), 'Twenty Years of Multi-Level Governance. Where Does It Come From? What Is It? Where Is it Going?', Journal of European Public Policy, 20 (6), 817-837.

Thorlakson, Lori (2009), 'Patterns of Party Integration, Influence and Autonomy in Seven Federations', Party Politics, 15 (2), 157-177.

Trondal, Jarle, Martin Marcussen, Torbjörn Larsson and Frode Veggeland (2010), Unpacking International Organizations. The Dynamics of Compound Bureaucracies, Manchester: Manchester University Press.

Waltz, Kenneth A. (1979), Theory of International Politics, Reading, MA: Addison-Wesley.

Wolf, Klaus-Dieter (2006), 'Private Actors and the Legitimacy of Governance Beyond the State. Conceptional Outlines and Empirical Explorations', in Arthur Benz and Yannis Papadopoulos (eds.), Governance and Democracy. Comparing National, European and Transnational Experiences, London: Routledge, pp. 200-227.

Wright, Deil S. (1988), Understanding Intergovernmental Relations, 3rd ed., Pacific Grove, CA: Brooks-Cole.

Zürn, Michael (2018), A Theory of Global Governance. Authority, Legitimacy, and Contestation, Oxford: Oxford University Press. 
Arthur Benz, Jörg Broschek, and Markus Lederer - 9781789908374 Downloaded from PubFactory at 04/26/2023 01:51:24PM 